\title{
Technology of obtaining REM-containing master alloy for silumins modification
}

\author{
Ernst Kh. $\mathrm{Ri}^{1}$, Khosen $\mathrm{Ri}^{1}$ and Mikhail A. Ermakov ${ }^{1, *}$ \\ ${ }^{1}$ PNU, 680035 Khabarovsk, Russia
}

\begin{abstract}
The technology of producing ligatures containing rear earth metals (REM) for modification of silumins has been developed. The optimum content ratio of yttrium, cerium and lanthanum 2: 1: 0.5 (15-20 wt.\% Y, 7-10 wt.\% Ce, 3.5-5.0 wt.\% La) for the synthesis of REM aluminides has been established. The peculiarities of the REM aluminides synthesis is studied using the methods of optical and electron microscopy and X-ray microanalysis, followed by the identification of the structural components of the Al-REM alloy. The microstructure of the master alloy is proved to consists of: REM aluminides (yttrium-containing and ceriumcontaining), metal base ( $\mathrm{Al}), \mathrm{Al}$ eutectic $+\mathrm{REM}$ aluminide and $\alpha+\mathrm{Si}$.
\end{abstract}

\section{Introduction}

There are very few publications on the development of compositions of master alloys from rare-earth metals for the silumins modification [1-4]. In the majority of works aluminum master alloys containing Ti, C, B, Ca, REM, P, and others are used [5].

Today Ce, La, Nd, Y etc. metals as well as mischmetals and transition metals or REM master alloys are widely used for modifying aluminum alloys, silumins in particular [6-19]. For example, the modification of the alloy Al-20 wt.\% Si [7] with cerium (0.3-1.0 wt.\%) contributes to the transformation of primary silicon of a large star-like shape to a small block shape, and the eutectic silicon of a needle-shape to a thin fibrous shape. In this case, the tensile strength $\sigma \mathrm{b}$ and relative elongation $\delta$ are increased by $68 \%$ and $53.7 \%$, respectively. The combined effect of Ce and Pr (0.6 wt.\%) [8], Ce and La (2.0 wt.\%) in A356 and A413 alloys with and without strontium [10-11], mischmetals based on La, Y and other alloys in Al-21 wt.\% Si [12-14] and ligatures from Ce and Mn [16] significantly change the silumin fractography and its mechanical properties.

The literature review provides no information on the problem of technology development of the Al-Y-Ce-La master alloy synthesis. In this regard the present work gives a detailed identification of the structural components of this master alloy and determines their microand nanohardness values.

\footnotetext{
*Corresponding author: ermakovma@yandex.ru
} 


\section{Research methods}

Aluminum of A95 grade was superheated to $900^{\circ} \mathrm{C}$ in the pure argon atmosphere and pure yttrium, cerium and lanthanum were introduced in the ratio - 2: 1: 0.5 (wt.\%: 15-20 Y; 7-10 Ce; 3.5-5.0 La) [1,2].

Micro X-ray spectral analysis was performed to determine the content of elements on an analytical research complex based on FE-SEM Hitachi Su-70 (Japan) with attachments for energy dispersive (Thermo Scientific Ultra Dry) and wave X-ray microscopic analysis.

The microhardness test was carried out according to the standard procedure on a Vickers instrument of Shimadzu HMV-G brand [20]. Nanohardness was measured on an Integra Prima atomic force microscope [21]. Local analysis was carried out on 3-5 points of sample sections, and the average chemical composition of the structural components - $\alpha$-solid solution, eutectic and intermetallic compounds $\mathrm{Al}_{x} \mathrm{Si}_{y} \mathrm{Fe}_{z} \mathrm{REM}_{v}$ - was determined.

\section{Results and discussion}

Table 1 shows the stoichiometry of the synthesized aluminides (yttrium-containing and cerium-containing) in Al-Y-Ce-La master alloy.

According to the state diagrams, yttrium forms $\mathrm{Al} 3 \mathrm{Y}$ aluminide, but cerium and lanthanum - $\mathrm{Al}_{11} \mathrm{Ce}_{3}$ and $\mathrm{Al}_{11} \mathrm{La}_{3}$ (respectively $\mathrm{Al}_{3.66} \mathrm{Ce}$ and $\mathrm{Al}_{3.66} \mathrm{La}$ ). The synthesized REM aluminide containing yttrium corresponds to the formula $\mathrm{Al}_{3,11} \mathrm{REM}$, but the standard one according to the state diagram - $\mathrm{Al}_{3} \mathrm{Y}$. The discrepancy between these values is insignificant (0.11 at.\% Al).

Table 1. Stoichiometry of REM aluminide.

\begin{tabular}{|c|c|c|c|c|c|c|}
\hline \multirow{2}{*}{ Aluminide REM } & \multicolumn{6}{|c|}{ Element composition, at.\% } \\
\hline & $\mathrm{Y}$ & $\mathrm{Ce}$ & $\mathrm{La}$ & ¿REM & Metal base & \multirow{3}{*}{$\begin{array}{c}\text { Eutectic } \\
\text { 95Al; 1,82Y; 0.75 La 0.81Ce; } \\
\sum \text { REM=3.38 } \\
\text { Impurities: } 1.0-1.77 \mathrm{Fe} ; \\
0-0.68 \mathrm{Si}\end{array}$} \\
\hline \multirow[b]{2}{*}{$\begin{array}{c}\text { Yttrium- } \\
\text { containing REM }\end{array}$} & 17.2 & 5.38 & 1.71 & 24.29 & $\mathrm{Al}, 100 \%$ & \\
\hline & \multicolumn{5}{|c|}{$\mathrm{Al}_{75,71} \mathrm{REM}_{24,29}=\mathrm{Al}_{3,11} \mathrm{REM}$} & \\
\hline \multirow[b]{2}{*}{$\begin{array}{l}\text { cerium-containing } \\
\text { REM }\end{array}$} & 6.44 & 8.62 & 6.26 & 21.32 & $\mathrm{Al}, 100 \%$ & \multirow{2}{*}{$\begin{array}{c}\text { 93.23Al; } 1.26 \mathrm{Y} ; 0.3 \mathrm{La} ; \\
0.45 \mathrm{Ce} ; \sum \mathrm{REM}=2.01 \\
\text { Impurities: } 1.0-1.77 \mathrm{Fe} ; \\
0-0.68 \mathrm{Si}\end{array}$} \\
\hline & \multicolumn{5}{|c|}{$\mathrm{Al}_{78.68} \mathrm{REM}_{21.32}=\mathrm{Al}_{3.69} \mathrm{REM}$} & \\
\hline
\end{tabular}

The resulting cerium-containing REM aluminide has a stoichiometry of $\mathrm{Al}_{3,69} \mathrm{REM}$, slightly different from $\mathrm{Al}_{3,66} \mathrm{REM}$. The discrepancy in stoichiometry is 0.03 at.\% $\mathrm{Al}$. From table 1 it follows that $\mathrm{Al}, \mathrm{Fe}, \mathrm{Si}$ and REM are present in the eutectic in certain amounts, the estimated structure of the eutectic corresponds to: $\mathrm{Al}+\mathrm{Al}_{3,66} \mathrm{P} 3 \mathrm{M}+\mathrm{Al}_{3} \mathrm{Y}+\mathrm{Si}+\mathrm{FeAl}_{3}$. The ironsilicon compounds of variable composition $\mathrm{Al}_{\mathrm{x}} \mathrm{Si}_{\mathrm{y}} \mathrm{Fe}_{\mathrm{z}}$ are also supposed to present.

The results of microhardness measurements showed that the yttrium-containing REM aluminide has a higher microhardness value (on the average $6547 \mathrm{MPa}$ ) than the microhardness of cerium-containing REM aluminide (the average $4695 \mathrm{MPa}$ ). The microhardness of pure aluminide is $254 \mathrm{MPa}$, and the microhardness of eutectic ( $\mathrm{Al}+\mathrm{REM}$ aluminide) is $423 \mathrm{MPa}$.

Fig. 1 shows the microstructure and location points of nanohardness measurement of structural components Al-Ce-La-Y of master alloy

It was established that nanohardness value of cerium-containing REM aluminide is 8560 MPa. Nanohardness of yttrium-containing REM aluminide is $9627 \mathrm{MPa}$. Accordingly, the nanohardness - and microhardness of yttrium-containing REM aluminide is significantly higher than that of cerium-containing REM aluminide. The average value of aluminum 
nanohardness corresponds to $1500 \mathrm{MPa}$. The average nanohardness value of the eutectic is $4650 \mathrm{MPa}$.

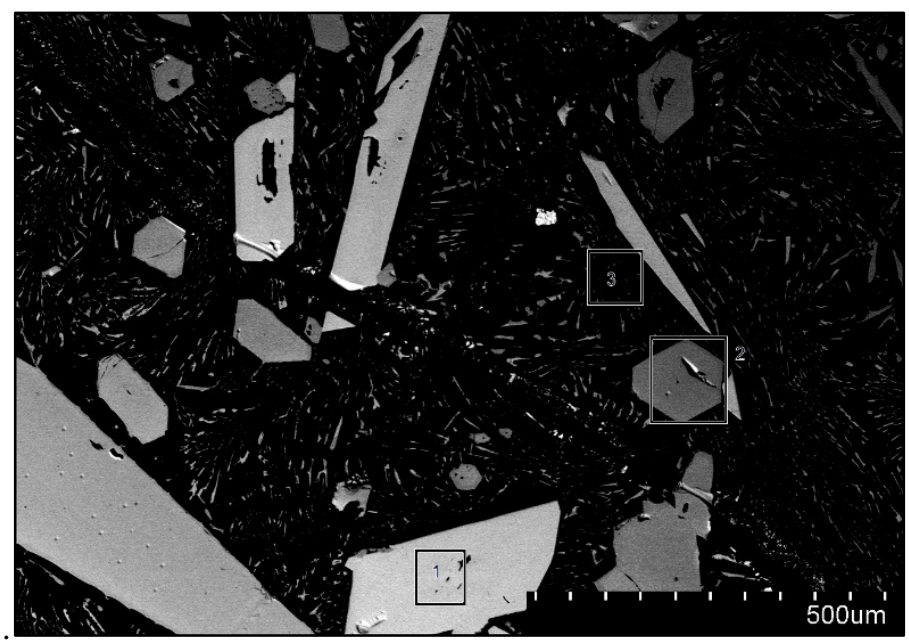

Fig. 1. Microstructure and location points of nanohardness measurement of Al-Ce-La-Y structural components of master alloy: 1- light crystal of REM aluminide (cerium-containing); 2 - darker crystal of REM aluminide (yttrium-containing); 3 - eutectic ( $\mathrm{Al}+\mathrm{REM}$ aluminide of variable concentration).

\section{Conclusions}

Micro X-ray analysis identified the structural components of the synthesized master alloy AlY-Ce-La:

- metal base consists of pure aluminum and eutectic $\left(A l+\mathrm{Al}_{\mathrm{x}} \mathrm{REM}_{\mathrm{y}}\right)$; microhardness of pure aluminum is $254 \mathrm{MPa}$, and nanohardness - $1500 \mathrm{MPa}$;

- yttrium-containing REM aluminide has the Al3Y stoichiometry ; microhardness is 6547 $\mathrm{MPa}$, and nanohardness is $9627 \mathrm{MPa}$;

- cerium-containing REM aluminide has the stoichiometry $\mathrm{Al}_{11} \mathrm{REM}=\mathrm{Al}_{3.66} \mathrm{REM}$ $\left(\mathrm{Al}_{3.66} \mathrm{Ce}, \mathrm{Al}_{3.66} \mathrm{La}\right)$; Microhardness - $4695 \mathrm{MPa}$, and nanohardness - $8560 \mathrm{MPa}$.

1) The increase in the addition of master alloy up to $0.5 \mathrm{wt} . \%$ contributes to the grinding of structural components - $\alpha$-solid solution and eutectic, and to crystallization of highly solid complex-doped aluminide $\mathrm{Al}_{\mathrm{x}} \mathrm{Si}_{\mathrm{y}} \mathrm{Fe}_{\mathrm{z}}$ with and without REM (in the original alloy).

2) Structural components of the AK7ch alloy are identified at the addition of the increasing amount of Al-Y-Ce-La master alloy ( $\alpha$-Si solid solution in aluminum, $\alpha+$ Si eutectic and complex-doped REM aluminides - $\mathrm{Al}_{\mathrm{x}} \mathrm{Si}_{\mathrm{y}} \mathrm{Fe}_{\mathrm{z}}$ and $\mathrm{Al}_{\mathrm{x}} \mathrm{Si}_{\mathrm{y}} \mathrm{Fe}_{\mathrm{z}} \mathrm{REM}_{v}$ ).

3) Regularities of changes in the element solubility and microhardness values of the structural components depending on the addition amount of master alloy Al-Y-Ce-La are revealed. Correlations between the silicon solubility in the $\alpha$-solid solution and its microhardness are found. The hardness of the HB alloy is stated to depend on the values of microhardness of the $\alpha$-solid solution and eutectic.

The study was carried out with financial support from the Ministry of Education and Science of the Russian Federation within the framework of the state assignment №11.3014.2017/4.6 "Investigation of the possibilities of obtaining REM - containing ligatures for the modification of metal alloys". The investigations were made using the equipment of the Center for Applied Materials Science of FSBEI HE "TOGU" and with financial support from 
the Ministry of Education and Science of the Russian Federation within the framework of the state assignments (State Reg. No. 11.7208.2017/7.8 and 11.7213.2017/7.8)

\section{References}

1. Modifier: Pat. 2521915. Rus. Federation: MPK51 SS22S35 / 00 / Hosen Ri, E.H. Ri, T.S. Zernova and others; Applicant and patent holder of the Pacific State University “Pacific State University” - № 2012151141/02; declare 11/28/2012; Ribl. 07/10/2014, Bull. № 19. - 5 p

2. Hosen Ri, E.H. Ri, S.N. Khimukhin, M.A. Ermakov, T.S. Khimukhina Production of aluminum alloys modificator from ligature, ARPN Journal of Engeneering and Applied Sciences, 13, pp. 1265-1272 (2018)

3. E.H. Ri, Hosen Ri, M.A. Kalaushin et al, Production of effective modifiers for highstrength cast iron and Al alloys, Foundry Production, 3, pp.2-5 (2017)

4. Hosen Ri, E.H. Ri, A.V. Goncharov, N.A. Slavinskaya, The use of REM-containing ligatures for microalloying of the cast alloy of the Al-Cu system, XVII International Conference on Science and Technology Russia-Korea-CIS. Yuzhno-Sakhalinsk, June 15-17, 2017: conference materials. - Novosibirsk: NSTU Riblishing House. (2017) pp. 350-354

5. V.I. Nikitin, K.V. Nikitin, Heredity in casting alloys (M.: Materials Science, 2005)

6. Xiao-hui Ao, Shu-ming Xing, Bai-shui Yu, Qing-you Han, Effect on the Cementing and Squeeze Casting, International Journal of Minerals, Metallurgy, and Materials, 25, pp. 553-564 (2018)

7. Qinglin Li, Tiandong Xia, Yefeng Lan, Wenjun Zhao, Lu Fan, Pengfei Li, The effect of rare earth cerium alloy and the tensile properties of hypereutectic Al-20\% Si alloy, Journal of Alloys and Compounds, v.562, pp. 25-32 (2013)

8. Xianchen SONG, Hong YAN, Xiaojun ZHANG, Microstructure and mechanical properties of the Al-7Si-0.7Mg alloy formed with an addition of $(\mathrm{Pr}+\mathrm{Ce})$, Journal of Rare Earths, 35, pp. 412-418 (2017)

9. W.X. Shi, B. Gao, G.F. Tu, S.W. Li, Hypereutectic Al-20\% Effect of Nd on microstructure and wear resistance of Si alloy, Journal of Alloys and Compounds, 508, pp. 480-485 (2010)

10. Wuhua Yuan. Zhenyu Liang, Chuanyang Zhang, Linjun Wei. Al-Mg-Si-Zr alloys based on AA 6201, Materials \& Design, 34, pp.788-792 (2012)

11. Y.C. Tsai, C.Y. Chou, R.R. Jeng, S.L. Lee, C.K. Lin. A356 alloy, International Journal of Cast Metals Research, 24, pp. 83-87 (2013)

12. D.H. Xiao, J.N. Wang, D.Y. Ding. H.L. Yang, Al-Cu-Mg-Ag alloy and its mechanical properties for its minerals, Journal of Alloys and Compounds, 352, pp. 84-88 (2003)

13. M.F. Ibrahim, M.H. Abdelaziz, A.M. Samuel, F.H.Samuel, H.W. Doty, Al-Si-based alloys, International journal of metalcasting, 52, pp. 1-17 (2019)

14. Li, Q., Li, B., Liu, J. et al., Modification of hypereutectic Al - 20 wt\% Si alloy based on the Yttrium and Al-5Ti-1B modifiers mixing melt, International Journal of Metalcasting, 13, pp. 367-383 (2019)

15. G.S. Mousavi, M. Emamy, J. Aass, Alassay, Casting alloy, ASC \& A., 556, pp. 573-581 (2012)

16. Joonyeon Chang, Inge Moon, Chongsool Choi, Recycling of Hypereutectic Al-Si Alloys through Rare Earth Metals, Journal of Materials Science,33, pp. 5015- 5023 (1998) 
17. Mario De-Giovanni, Talukder Alam, Rajarshi Banerjee, Prakash Srirangam, 3D Atom Pro Tom Al-Si alloys, JOM. 70 (2018)

18. Kazuhiro Nogita, Stuart D. McDonald, Arne K. Dahle, Eutectic Modification Al-Si Alloys with Rare Earth Metals, Materials Transactions, 45, pp. 323-326 (2004)

19. Chao Fan, Si-Yuan Long, Huai-de Yang, Xiang-jie Wang, Jun-cheng Zhang, Influence of Ce and Mn in addition to $\alpha$-Fe morphology in Al-Si alloy, International Materials, 20, pp. 890-895 (2013)

20. GOST R ISO 6507-1-2007. Metals and alloys. Vickers hardness measurement. Part 1. Method of measurement (M.: Standartinform, 2008)

21. GOST 8.748 - 2011 (ISO 14577-1: 2002) Metals and alloys. Measurement of hardness and other characteristics of materials with instrumental indentation. Part 1. Measurement methods (M.: Standartinform, 2013) 